\title{
Stock market trading in space and time: Information and HSBC share prices in New York, London and Hong Kong, 2006-2009
}

\author{
Working Paper in Employment, Work and Finance 10-08
}

\author{
Dariusz Wójcik \\ School of Geography \& the Environment and St.Peter's College, Oxford University \\ South Parks Road, OX1 3QY, Oxford, United Kingdom \\ dariusz.wojcik@spc.ox.ac.uk
}

\begin{abstract}
This paper investigates the circulation of information on secondary stock markets, using the case study of HSBC shares traded on the exchanges in New York, London, and Hong Kong. The distribution of price discovery is analysed across the three markets, within a 24-hour cycle of trading, and in the period between 2006 and 2009, showing a clear relationship with the distribution of private information about HSBC. London, the seat of HSBC headquarters, home to most of its decision makers and key business relationships, dominates price discovery. Hong Kong, the former home of HSBC and hub of its Asian operations is second. New York, unable to rival London or Hong Kong's access to private information about HSBC, is last. Its role in price formation was particularly weak during the financial crisis, when confidence in publicly available information was at its lowest. The role of Hong Kong increases over time. As its Group Chief Executive Officer is relocating from London to Hong Kong, HSBC is returning to its Chinese roots. Trading activity and price discovery for HSBC shares may follow suit.
\end{abstract}

Keywords: information, stock market, price discovery, HSBC, financial centres

JEL codes: D8, G01, G12, G15

\section{Introduction}

The Efficient Market Hypothesis and the Modern Portfolio Theory assume perfect ubiquitous information. This means that everybody everywhere has complete and identical information. One implication of these theories is that no investor has an advantage in trading financial assets. Another implication is that asset prices should not be affected by the location of trade. Claims on the same set of risky cash flows should be assigned the same value, wherever they are traded. 
There is abundant research dispelling the myth that no investors have an informational advantage in secondary stock markets (Wójcik 2009a). It shows that proximity to the sources of information relevant to stock prices (whether this is the location of corporate headquarters or an international financial centre) is an important factor that may give investors who are local to these sources an advantage over those who are distant. We should note, however, that this has potential consequences for the role of the location of trade. If the location of the trading platform is related to the composition of investors who use this platform, e.g. if investors prefer to use trading platforms in their home country or time-zone, then the location of trade matters for asset prices. Indeed, there is a considerable amount of evidence in financial economic research that for stocks listed in multiple markets, the home market leads price discovery, indicating that investors who trade on home markets have an informational advantage over those trading in foreign markets (Karolyi 2006). The significance of proximity has also been demonstrated in domestic contexts, for single listed stocks, where investors who live close to headquarters of listed companies contribute more to the price discovery of their stocks than do investors who live further away (Anand et al. 2008).

Trading of financial assets is not just an issue of where; it is also a related issue of when, particularly if we think about financial trading at a global level. As shown by Clark and Thrift (2005) even foreign exchange trading, as one of the most transparent and globalised financial markets, is predicated on time- and spacesensitive processes. It is spread across the three major global time zones, with trading activity peaking at the opening and closing of the foreign exchange markets in Tokyo, London, and New York (in this order). London has a particularly important place in the daily cycle, as its trading hours overlap with those of Tokyo and London. If London did not exist, it would have to be invented at much the same place in time and space between New York and East Asia. In sum, the trading of financial assets can be clustered in space and time, even if technology allows trading from anywhere at any time.

This paper aims at contributing to our knowledge about the spatiality and temporality of financial trading by asking two general questions. First, where and when does stock price discovery take place? And second, how do general market conditions and sentiment affect the distribution of price discovery? Does price discovery, for example, differ between a bull and bear market? These broad questions will be investigated through a case study of HSBC share prices on stock exchanges in Hong Kong, London, and New York, the leading stock markets of the world, in the years 2006 to 2009 . While studies on stock price discovery typically analyse the relationship between two trading venues, this case study addresses stock price discovery around the globe and around the clock. To the best of my knowledge, this is also the first academic analysis of the impact of the recent financial crisis on stock price formation, and the first study assessing the price discovery for HSBC in a tri-market context.

The results show that each of the three markets plays a part in the price discovery of HSBC shares. This is not surprising considering the global presence of the 'world's local bank', and the monopoly on price discovery that each of the three markets enjoys for a part of the 24-hour day. When the trading hours 
overlap (Hong Kong with London, and London with New York) the price discovery process is amplified, which highlights the role of heterogeneous information. Diversity of perspectives and expectations that come from different markets seem to enrich the market place. Although the 24-hour trading cycle appears like a conveyer belt passing information from Hong Kong to London, on to New York, and then to Hong Kong again, the hierarchy in contribution to price discovery is clear. London - the seat of HSBC's headquarters and regulatory jurisdiction, the locus of its relations with professional service providers, and the home for many of its decision-makers - dominates. Hong Kong - the former headquarter location, and the control centre of HSBC's fast growing Asian operations - takes the second place. New York, although by far the largest centre of stock market trading in the world, is left with the third place.

The main finding of our analysis of price discovery over time is that while New York was able to compete with London and Hong Kong in the relatively optimistic and stable market conditions in 2006 and the first three quarters of 2007, its significance in price discovery diminished when investors became uncertain and markets more volatile in late 2007. At the peak of the crisis, between September 2008 and February 2009, New York's contribution to price discovery was even lower, and has not fully recovered until the end of 2009.

The paper proceeds as follows. The next section places the research questions in context, by reviewing the theoretical and empirical literature on price discovery in space and time. Section 3 introduces the HSBC case study, and section 4 proposes how to divide the period of study 2006-9 into sub-periods based on general stock market conditions. Sections 5 and 6 constitute the analytical core of the paper, presenting the distribution of HSBC price changes around the clock, and the transmission of price changes across the three markets. Section 7 concludes and offers implications for understanding the nature of stock markets.

\section{Price discovery in space and time}

There are clear benefits for trading in a given asset to concentrate on a single trading platform accessible to all investors and traders. Sellers benefit from a large number of buyers and vice versa. Trades can be completed more quickly, and the risk of large buy or sell orders raising or lowering the market price is smaller. As the old saying goes, liquidity attracts liquidity (Harris 2003). On the other hand, the concentration of trading on one platform implies a monopoly of the provider of the platform, which in turn points to the benefits of competition between trading platforms, even if it comes at the expense of fragmenting the market. On stock markets, trading individual stocks on multiple trading platforms is common, and typically takes the form of listing and trading a stock on different stock exchanges. One question that arises as a consequence is that of the relationship between prices of the same stock traded on different exchanges. of course, there is arbitrage that would quickly restore any significant differences, but the question remains about which market/exchange leads in terms of price change and which follows. Which market discovers the price, thus revealing the possession of superior price-relevant information? 
There is a rich body of literature on price discovery in cross-listing. The main conclusion of these studies is that home markets play a dominant part in price discovery. Home market of a company is typically defined as the stock exchange in the country where the company is headquartered. To illustrate the homemarket advantage, imagine a German company listed in New York. While both German and US investors can freely trade on either Frankfurt or New York exchanges, the trading of German investors is likely to concentrate in Frankfurt and that of US investors in New York. Even if trading costs in Frankfurt for US investors are not higher than trading at home, US investors would prefer to trade German shares by day, not at night according to US time. As a result, trading in Germany is likely to reflect more price-relevant information. While the crosslisted company would publish a lot of information in English, available around the world, there will always be private (non-public) information available only in Germany. It is Germany where the decision-makers of the company and their families are likely to live and socialize. This is where people they went to school with live. This is where the law, banking, and other advisers and service providers are likely to be. This is where legal and regulatory changes affecting the company most originate and can be best understood. In sum, the home market advantage is not about the location of the trading platform itself. It is about who trades on it, and what access to information they have. A good case in point is a study by Chan, Menkveld and Yang (2007) demonstrating that for firms from Mainland China listed in Shanghai or Shenzhen, but traded on two separate segments - A-shares by domestic investors, and B-shares by foreigners - A-share market dominates price discovery, as domestic investors possess superior information.

To be sure, proximity between the location of corporate headquarters and investors (and traders) is important also in a domestic context. A study by Anand et al. (2008) on price discovery of US stocks traded on NASDAQ shows that market makers closer to firms' headquarters trade more frequently and contribute more to price discovery than distant market makers. They can predict future prices better. When firms relocate their headquarters, price discovery of formerly local market makers declines and that of newly local market makers increases. Finally, the study shows that market makers that acted as lead underwriters in the firm's initial or later public offerings or advised the firm on mergers \& acquisitions (or other investment banking issues) play a particularly prominent part in price discovery. In this sense, the geographical bias - the role of proximity between an issuer and its underwriter (-s) - carries over from primary to secondary market (Wójcik 2009b).

Anand et al (2008) thus remind us of the significance of intermediaries in price discovery. In fact, Anand and Subrahmanyan (2008) show that intermediaries account for a greater part of price discovery than other investors. They also point out that intermediaries incur little marginal cost in monitoring the market for the purposes of their proprietary trading (trading on their own rather than clients' account), as they do it for their customers anyway. By extension, financial centres are important for understanding price discovery not only because they represent concentrations of corporate headquarters and investors, but also as concentrations of intermediaries, with investment banks in the lead. 
The role of proximity between issuers and investors in price discovery depends on the characteristics of the home market, the host market, and the company in question. The advantage of domestic or local investors is less likely with regard to firms from immature, illiquid markets. In immature markets, even if investors have privileged access to stock-specific price-relevant information, they may lack skills to exploit it and/or to combine it with information on relevant international and sector-wide factors. If home market is illiquid, the paucity of trades would slow down the incorporation of new information into the price. The NYSE specialists interviewed by Pascual et al. (2006) agreed that they could only be active in the price discovery of stocks from illiquid and immature markets, and could not compete with liquid home markets. For Spanish companies, traded very actively on the Spanish Stock Exchanges, the paper found that the NYSE contributed little to price discovery, functioning as a mere satellite of the Spanish market.

With regard to the characteristics of the host market, what matters in addition to liquidity is sector-specific expertise. Companies like being traded where their peers are traded (Wójcik 2010). In consequence, a host market should have a particular chance to contribute to price discovery if investors and intermediaries trading on it have sector-specific expertise. Research on stock analysts, however, indicates that home-country expertise influences the quality of forecasts more than sector-specific expertise (Sonney 2009). Finally, considering the features of traded companies themselves, the local and home advantage in price discovery should be larger for firms that produce less public information in relation to private information. This would apply to smaller firms, those with less international activity, not included leading stock market indices, but also companies that irrespective of their size and scope are less transparent. Drawing on research from Hupperets and Menkveld (2002), Clark et al. (2006) point out that Dutch companies with poorer transparency and corporate governance have more price discovery in Amsterdam in relation to New York, where they are cross-listed.

Let us move from the question of where to the related issue of when price discovery takes place. Starting with the basics, there are advantages to trading 24 hours a day. The whole world never sleeps, and globalization means that events relevant to stock prices may happen any time around the clock. This has implications for competition between trading platforms from different time zones. Research focused on events when foreign markets attempted to capture the stock trading volume from a home market shows that the success of such attempts (if any) is in most cases only transitory, and the trading tends to return to the home market, even with regard to corporations with global scope and brand, like Daimler Chrysler (Karolyi 2003). At the same time it shows that return to the home market happens to a larger extent if the foreign market is in a time zone near the time zone of the home market (Halling et al. 2008). Thus, competition between trading platforms within time zones is much more severe than between them. It should be stressed, however, that a successful establishment of trading for a stock in a different time zone does not mean that the new location of trading automatically acquires significance in price discovery. A market in a different time zone at least tries to discover the price while the home market is closed, but it may still have very small price impact. 
Menkveld et al. (2007) for example show that despite a large and growing market share, the NYSE still played a minor role in the price discovery of crosslisted Dutch shares.

Another way to look at the temporality of price discovery is to focus on the distribution of trading activity over the trading hours of a given platform. Here the tendency is for trade to cluster in time, for much the same reason it tends to cluster over trading venues - liquidity. A typical profile of trading activity over the period of trading hours of a stock exchange is high volume and volatility at the open of trading, and another, but much smaller peak of activity right before the close. Market opening seems to be the time when a lot of information is revealed, after it has been accumulated overnight. Close is simply the last opportunity to trade. With cross-listing, the situation gets more interesting, as the trading hours of different exchanges can overlap, creating a period between the opening of the following market and the closure of the preceding. Literature shows that overlaps exhibit particularly high levels of activity (in terms of volume, volatility, and bid-ask spreads) and price discovery (Werner \& Kleidon 1996). In overlaps traders can use either market to trade and big trades can be split to prevent negative price impact (Hupperets \& Menkveld 2002). Most importantly, however, overlaps are periods when the clash of price-relevant information from different geographical sources is most intensive. This is when heterogeneous information, based on different expectations hits the market to determine the price (Clark \& Wójcik 2001). As a practical reflection of the value of overlapping trading hours many stock exchanges have extended their trading hours. In 1990s the London Stock Exchange traded only between 10 and 16, at present it trades from 8 to 16:30.

In contrast to a substantive body of research being available on the role of time zones and trading overlaps, there is little research investigating how the distribution of price discovery changes over longer periods of time. Morover, while there is research on how financial crises affect correlations between stock market indices (Markwat et al. 2009, Wang et al. 2009), there is little on how they affect price discovery. One exception is the work of Neumark et al. (1991) showing that for thirty days following the October 1987 stock market crash, the Tokyo and London prices of multiple-listed stocks predicted their New York prices. Otherwise, Tokyo and London were relatively uninformative for New York prices. Although their research covers a period when the costs of arbitrage (trading across markets) were incomparably higher than at present, it does suggest that during market turmoil, home-country markets may become more important. In a recent paper, Clark et al. (2006) analyse the corporate governance crisis at Ahold, the Dutch retail trade corporation, following the revelation of an accounting fraud in 2003, and its impact on price discovery in the Ahold stock price on the Amsterdam and New York stock exchanges. They document that while until 2003 New York had some (albeit minor) contribution to price discovery, its significance faded away under conditions of uncertainty during the corporate crisis. The message is that during market turmoil historical and publicly available information become less relevant. After all, a sudden dramatic drop in price means that old insights failed, alternatives are needed. Lack of confidence in the future of a stock involves distrust in publicly available information about the company. Inside information becomes of particular value. 
The objective of this paper is to advance our understanding of price discovery in time and space via a case study of HSBC share prices on the London Stock Exchange (LSE), the Hong Kong Exchanges and Clearing Ltd (HKEx) and the New York Stock Exchange (NYSE) in the period 2006-9. This case study allows a focus on the role of information in price discovery, as there are few factors that would interfere with the analysis. All three markets are completely accessible to foreign investors and there are no language or regulatory barriers to cross-border arbitrage between them. To be sure, HSBC is traded on the NYSE in the form of American Depositary Receipts. With low arbitrage costs, this should not inhibit the role of the NYSE, and so HSBC ordinary shares traded on the LSE, the HKEx and ADRs traded on the NYSE can be treated as subsititutes (Karolyi 2003). Trading in HSBC shares is very high in all three markets. All three markets use continuous trading, so there are no major differences in market structure. In addition, as a bank HSBC belongs to the sector most implicated in the recent financial crisis.

\section{The HSBC case}

This section introduces HSBC with particular attention to three related questions. Where is the home stock market of HSBC? How important are Hong Kong, London and New York as the loci of information about HSBC? Has the geographic distribution of information about HSBC changed in the period 20069? To shed light on these issues, I start with the basics on HSBC's history, size and scope, moving on to its share ownership structure, board of directors, and finishing with changes over the period 2006-9. Figures and other information mentioned in this section are valid for March 2010 unless otherwise stated.

HSBC Holdings Plc, the parent company of the HSBC Group, is incorporated in the UK, with its head office in London, hosting 8,000 staff at 8 Canada Square in Canary Wharf. The Group is thus domiciled in the UK for tax purposes, and the Financial Services Authority is its lead regulator. Its history started with the founding of Hong Kong Shanghai Banking Corporation in 1865. It was only in 1993, the year following its acquisition of Midland Bank Plc, that HSBC moved its headquarters to London. To promote the Group as a whole HSBC established a unified brand name in 1999 and in 2002 launched the famous campaign 'The world's local bank'. HSBC offers a full scope of financial services, delivered via 8,000 offices in 88 countries, employing over 300,000 people and serving 100 million customers. With assets of $\$ 2,400 \mathrm{bn}$ at the end of 2009 , HSBC was one of the largest corporations in the world.

The share capital of HSBC is divided into approx. 17.5bn ordinary shares. The primary listings of HSBC are in London and Hong Kong. Its American Depositary Receipts (each representing 5 ordinary shares) are listed in New York, with additional listings on Euronext Paris and the Bermuda Stock Exchange. Trading volumes on the last two, however, are much smaller than in London, Hong Kong or New York. HSBC has approx. 220,000 shareholders in 119 countries, with two-thirds of shares owned by individual and one-third by institutional investors. While approx. 1,000 largest shareholders had 95\% of shares, there were only five shareholders with more than $1 \%$ of the share capital (with Legal 
\& General in the lead owning 3.16\%). As such, the ownership structure of HSBC has to be considered as extremely diluted. The wide ownership of HSBC is not surprising. With a global brand and worldwide operations, the company appeals to investors offering an exposure to emerging markets with a perceived safety of being anchored in the UK regulatory environment. An important implication of the wide ownership base is that there are no shareholders who could be considered insiders just by the virtue of the percentage of share capital they hold. This leaves HSBC's directors and executives as the main insiders.

The Board of Directors has 21 members: 6 executives, and 15 non-executives. The Chairman of the Board of directors, Stephen Green (who was the Group Chief Executive in the years 2003-6) is based in London. The Group Chief Executive (since 2006), Michael Geoghegan was in early 2010 in the process of moving from London to Hong Kong. His Deputy is based in Hong Kong, while the Chairman of HSBC Bank (China) and HSBC Taiwan is based in China. Reflecting HSBC's incorporation in the UK, the Group Finance Director (responsible i.a. for reporting and compliance) is based in London, and so is the Chief Executive of HSBC Asset Management. The list of top executives completes the Group Managing Director (who is also the Chief Executive of HSBC North America but is not a board member), based in New York. Out of 15 non-executive directors 7 are based in the UK, 3 in Hong Kong, 3 in the US, 1 in France and 1 in India. Directors' shareholdings, $6.3 \mathrm{~m}$ shares in total, are minute in relation to the overall share capital of HSBC, but nevertheless significant. The Chairman, the Group Chief Executive and the Chief Executive of HSBC Asset Management, each with more than 700,000 shares are among the top 1,000 shareholders in HSBC.

HSBC went through the financial crisis of 2007-9 relatively unscathed. It closed its subprime mortgage operations in the USA in 2007, as well as sold and leased back its head office building in Canary Wharf. It did downsize, disposing of approx. 2,000 branches in 2008 and 2009, and loosing 25m customers, but its reach in terms of countries actually grew. In 2008, in contrast to the Royal Bank of Scotland, Lloyds and Barclays, HSBC did not need financial assistance from the British government. In December 2008, the Group injected $£ 750 \mathrm{~m}$ into the UK subsidiary from its own sources. In 2009, with the reputation of a leading bank relatively unaffected by the crisis, HSBC was awarded as 'Global Bank of the Year' in the Euromoney Awards for Excellence. It raised \$18bn from the stock market through a rights issue, and was back in expansion mode, with particular focus on Asia, its most profitable market.

Let us go back on questions posed at the start of the section. The review of the basic facts thus far suggests that London is the main locus of information about the company, with Hong Kong in the second, and New York definitely in the third place. Recently, there is a sense of increasing importance of Hong Kong to HSBC. Not only is the Group Chief Executive moving to Hong Kong, but since 2008 the Annual General Meeting of shareholders held in London is preceded with an informal meeting of shareholders with the Group Chief Executive. Further insight can be gleaned from the geographical breakdown of HSBC's total operating income (table 1). Between 2006 and 2009, the share of Asia-Pacific operations increased from $25 \%$ to $30 \%$. The share of North and Latin America dropped from $42 \%$ to $34 \%$, while the share of Europe increased from $33 \%$ to 35\%. These 
are not dramatic changes, but they may imply an increasing role of Hong Kong and declining role of New York, as the locus of information on HSBC. As HSBC is returning to its Chinese roots, the Chinese sources of information about HSBC may grow in significance.

[table 1]

Table 1 summarises the global character of HSBC. In 2009, the three major time zones had almost equal shares as its sources of income. It is clear then that events affecting HSBC can happen around the clock. In this context, it is worthwhile noting that in 2008 HSBC opened virtual teleconferencing rooms to give its executives scattered around the world 'in-person' meeting experience. These are available in Hong Kong, Dubai, London, New York, Chicago, and Mexico City. This reminds us that HSBC is a really exacting test for price discovery. If the analysis reveals an uneven distribution of information about 'the world's local bank', then the role of geography in stock market trading could hardly be questioned.

\section{Stock markets and the global financial crisis 2007-9}

In order to analyse the price discovery for HSBC over time, the period of 2006-9 will be divided into sub-periods based on the prevailing market conditions and sentiment. An alternative would be to identify key dates within the period and observe how price discovery changes within time windows of varying length (10 or 30 days for example) prior and after these dates. This alternative is not pursued because in contrast to the crises of 1929 or 1987, the stock market downturn that accompanied the crisis of 2007-9 did not produce a distinctive 'black' day on stock markets. To be sure, many consider Lehman Brothers' filing for bankruptcy on 15 September 2008 as a turning point, but although major stock market indices fell on the day, they recuperated to their pre-15 September values within a week, before they fell again the following week. This is related to the fact that the recent crisis originated outside of the stock markets, in the subprime mortgage sector and the OTC-traded market for Collateralised Debt Obligations.

Figure 1 charts stock market performance over the 4-year period under consideration. It presents the broadest indices for the stock markets in Hong Kong (Hang Seng Composite Index - HSCI), the UK (FTSE All-Share- FTSEAS), and the New York Stock Exchange (NYSE Composite - NYSEC). Daily close values are used for all indices. It also shows the trajectory of the HSBC share price as traded on the LSE (using daily close prices in GBP). All data are from Factiva. There is no need at this stage to compare HSBC price across exchanges. Arbitrage is bound to keep these prices close to each other, and whatever differences there are, they are irrelevant to the identification of general stock market trends. Before I move to identifying sub-periods, three general features evident in figure 1 are worth mentioning. First of all, considering a high level of integration of international stock markets, it is not surprising for the major indices (and particularly NYSEC and FTSEAS) to be highly correlated. HSCI moves in tandem with the other two, but with more exaggerated ups and downs. This is typical of 
emerging stock markets, popular with foreign investors as fast-growth markets in good times, but often abandoned in bad times. Finally, it is not surprising to see HSBC, as a bank, to underperform the all-sector indices.

\section{[figure 1]}

Four distinctive periods can be identified by analyzing market values and their volatility (measured as the standard deviation of daily close-to-close returns, as shown in table 2). The first is a period of growth and low volatility, lasting from the start of 2006 until the end of October 2007 when the market indices along with HSBC price peaked. Total growth over the period ranged from $20 \%$ for FTSEAS to $130 \%$ for HSCI. This was the tail of a bull market that started in 2003. In November 2007 a slow decline starts coupled with a high degree of uncertainty illustrated with standard deviations of daily returns almost double their values from the preceding period. In other words, this is a picture of the stock market waiting for a verdict. Once the severity of the crisis becomes evident in September 2008, the markets crash in a double-dip pattern. The sharp decline of September and October is followed by stagnation in November and slight recovery in December, only to be followed by another crash in January and stagnation in February 2009. This is the peak of the crisis, with volatility twice higher than in the period of slow decline, with markets losing between a third and a half of their value. The green shoots of recovery are seen only in March, marking a return to growth. By the end of 2009 , FTSEAS grew by $43 \%$, NYSEC by $56 \%$, and HSCI by $72 \%$, but all of them were far from their record values from 2007. It was also a period of tentative growth, with volatility comparable to that prevailing in the period of slow decline.

[table 2]

\section{HSBC price changes around the clock}

Having reviewed the existing research on price discovery, sources of information from HSBC, and divided the four years under investigation into sub-periods, its is time to analyse the distribution of price discovery. The analysis will proceed in two stages. First, I will compare price changes for different parts of a 24-hour trading day. The next section will focus on the transmission of daily price changes between the three trading venues.

The opening and closing times of trading in Hong Kong, London and New York divide a trading day into six parts. Figure 2 shows the 24 -hour clock for the three exchanges according to GMT time and time differences that prevail for most of the year (late March to late October). For the rest of the year Hong Kong opens and closes one hour earlier (in relation to London) due to daylight time saving in London. The interaction of the latter with daylight time saving in New York, in turn, produces short spells in March and October, when New York opens and closes one hour earlier (in relation to London).

[figure 2] 
The following two-part question is asked. What is the role of each part of the 24hour cycle in moving the stock price of HSBC, and how does this role change over time? To answer this question, the absolute price change is calculated for each part of the day on each day (when there is trading on all three exchanges), and then average absolute price change is calculated for each part of the day for the whole 4-year period and each sub-period. The data used are the open and close HSBC stock prices from the NYSE (ADR price divided by 5), the LSE (converted into USD), and the HKEx (also converted into USD). All data were obtained from Factiva. For example, the absolute price change for the overlap between Hong Kong and London is that between the London open and the Hong Kong close price. To summarise this method, absolute price changes are used as an indication of the use of price-relevant information during different parts of the day, building on the method first developed by Barclay and Warner (1993).

Appendix 1 gives details of mean absolute price change for day-parts in each period. Figure 3 summarises the results showing the share of each day-part in the sum of mean absolute price changes for each period. Over the whole 4-year period the time between Hong Kong close and New York open, when only London trades HSBC shares, contributes most to price changes - 22\%. The second largest contribution - 18\% - happens between Hong Kong open and London open, when Hong Kong has monopoly over trading. The time of New York's monopoly over trading (from London close to New York close) contributes $15 \%$ of price changes. London holds the first, and Hong Kong holds the second position in price changes throughout the four periods. This seems to confirm our expectations about the role of the three trading locations in the price discovery for HSBC shares. London trading is most likely and New York least likely to incorporate private information about HSBC into its share price, with Hong Kong in the middle.

\section{[figure 3]}

Significant price changes take place during the two trading overlaps, one between Hong Kong and London, the other between London and New York. Together they contribute as much as $30 \%$ of price changes. This is even more impressive if we consider how short these overlaps are. On average throughout the year the overlap between Hong Kong and London lasts only half an hour, and that of London with New York two hours, compared to the periods of $6 \mathrm{hrs}, 6 \mathrm{hrs}$, and 4.5 hrs when Hong Kong, London, and New York respectively, hold monopoly over price discovery. This finding seems to confirm our expectations about the role of heterogeneous information driving the market during trading overlaps. Price discovery appears particularly intensive when Hong Kong and London overlap, adding to the significance of these trading locations.

There is a significant fluctuation in the contribution to price changes over the four sub-periods. The price changes on HSBC's core home market - London are particularly large in the run-up to and at the peak of the crisis. Trading overlaps have the largest contribution to price changes at the peak of the crisis. It appears that private information, and heterogeneous information plays a particularly important role in the conditions of uncertainty. In contrast, New York contributed most to price changes in the period of growth and relatively low 
volatility. It seems that the optimistic and stable market made those trading in New York confident in the public information available to them, and unconcerned about their poor access to private information in relation to Hong Kong, and particularly London. They lost some of this confidence, however, when the markets turned from a bull to a bear.

\section{Transmission of daily price changes}

The preceding section took the simplest possible approach to analyse contribution to price discovery. While price changes are important in identifying periods of time and trading venues that bring new information to the marketplace, comparing absolute price changes is a static method that does not inform us whether price changes in one market actually influence those on other markets. Put differently it tells us about a potential of a market to influence others but not the actual influence. To extend the analysis, this section evaluates the transmission of daily price changes from one trading venue to another, by regressing the daily return on HSBC shares on each of the three markets on the daily returns on HSBC shares on the preceding markets. The following three regressions are estimated:

$r_{t}^{H K}=\alpha_{1}+\beta^{N Y} \cdot r_{t-1}^{N Y}+\gamma^{L O} \cdot r_{t-1}^{L O}+\varepsilon_{1}$

$r_{t}^{L O}=\alpha_{2}+\beta^{H K} \cdot r_{t}^{H K}+\gamma^{N Y} \cdot r_{t-1}^{N Y}+\varepsilon_{2}$

$r_{t}^{N Y}=\alpha_{3}+\beta^{L O} \cdot r_{t}^{L O}+\gamma^{H K} \cdot r_{t}^{H K}+\varepsilon_{3}$

Rate of return $r$ on day $t$ in Hong Kong, for example, is calculated as the difference between the close price on day $t$ and the close price on day $t-1$, expressed as a percentage of the close price on day $t$-1. Rate of return on day $t-1$ is calculated with the close price on day $t-1$ and day $t$-2. Hong Kong returns are estimated as a function of New York and London returns from the preceding day. London returns are estimated as a function of Hong Kong returns from the same day, and New York returns from the preceding day. Finally, as New York opens and closes last, its returns are estimated as a function of London and Hong Kong returns from the same day. The coefficients of most interest in the equations are betas, as they reflect the extent to which return on a given trading venue influences the return on the following venue. The regressions are estimated for each of the fours sub-periods.

Figure 4 shows beta coefficients for the three exchanges. There are no gamma coefficients significant at $1 \%$ level, while all betas are significant at $0.1 \%$ level. London has by far the strongest influence on the following market (i.e. New York) throughout the period. Hong Kong comes as a strong second; New York comes third. Consistently with the results of the receding section, the influence of New York is strongest in the relatively bullish market of the first period, 2006 to October 2007, when it rivals the influence of Hong Kong. In the period of heightened uncertainty (2) and during the crisis itself (period 3) New York however falls far behind Hong Kong. 


\section{[figure 4]}

It is not surprising to see beta coefficients fall during the crisis. High uncertainty and volatility mean that prices are likely to change in the opposite direction than those on the preceding market. This gives a V-shaped pattern of coefficients for London and New York over time. Hong Kong however does not follow this pattern. Its impact on the following market (London) actually increased in period 2 , and then fell less than the impact of New York and London in period 3. This implies that while the absolute price changes in Hong Kong did not grow nearly as much in periods 2 and 3 as they did in London (see the shrinking share of Hong Kong in figure 3), they had a larger influence on London than in period 1. Overall between 2006 and 2009, Hong Kong was the market the influence of which increased most. It seems that in the run-up to and during the crisis Hong Kong, the second home of HSBC, joins London's efforts in price discovery, while the role of New York recedes. These findings may also reflect the growing significance of Hong Kong as the hub of HSBC's expanding operations in Asia.

Before we close the analysis, let us relate the results on price discovery to data on trading volumes for HSBC shares across the three markets and the four subperiods. As table 3 shows on average over the whole period of 2006-9 London traded twice as many HSBC shares as Hong Kong, and seven times as many as New York. Thus, the order of significance in trading volumes is the same as that for price discovery. In addition, consistently with the results on price discovery, we see the share of Hong Kong in trading volume increasing gradually over time, from $40 \%$ of London's in period 1 , to nearly $70 \%$ in period 4 . For New York, however, the declining position in price discovery during the crisis is accompanied by impressive increases in trading volumes. While the analysis of the relationships between price discovery and liquidity is beyond the scope of this study, the results suggest that the structure and dynamics of trading volumes can but does not have to be correlated with the structure and dynamics of price discovery. While being the smallest market for HSBC, New York still trades millions of HSBC shares a day, which is not a level of liquidity that could in its own right significantly inhibit price discovery in New York.

[table 3]

One last consideration worth posing for is the role that HSBC shares play on each of the three exchanges. In Hong Kong, HSBC is the most traded share and the biggest component of the Hang Seng Index. In London, it is one of the most traded shares, and an important component of FTSE100. In New York, as an ADR, HSBC would be considered as average in its market capitalization and trading values, and is not a part of the elite Dow Jones Industrial Average. In theory, while HSBC is the same company wherever its shares are traded, the role it plays on different markets may influence the distribution of price discovery. As research in behavioral finance has shown, the largest and most visible stocks are more likely to attract investors' and traders' attention and effort (Barber Odean 2008). While this should not make a big difference for price discovery between London and Hong Kong, the relative insignificance of HSBC for the US stock market may contribute to weak price discovery for HSBC in New York. 


\section{Conclusions and implications}

The objective of this paper was to document and account for the circulation of information on secondary stock markets. Specifically, I have analysed the distribution of price discovery for HSBC shares across three of the leading stock exchanges in the world: the NYSE, the LSE, and the HKEx. The distribution of price discovery has also been investigated over time, within a 24-hour cycle of trading, and in the four-year period between 2006 and 2009, straddling the recent financial crisis. HSBC is one of the world's largest corporations, with global scope of operations as well as a global image. HSBC shares are traded by exchanges in the leading global financial centres, and their trading between these exchanges (arbitrage) is subject to minimal costs. Thus, the challenge was the following. If one can show that the distribution of price relevant information across the three exchanges and financial centres is important for price-discovery of HSBC shares, then one could only expect the geographical distribution of information to be more important for nearly any other company.

I found that there is a clear hierarchy of markets in terms of their contribution to the discovery of HSBC stock price. This hierarchy is consistent with the expected distribution of price-relevant information across the three global financial centres. London dominates. It is the seat of HSBC headquarters, home to most of its top decision makers, and home to its relations with key service providers, such as investment banks, security analysts, law and accountancy firms. Hong Kong comes second. It is the hub of HSBC's operations in Asia; it is essential to its identity and the claim to being the leading bank for emerging markets. It is also home to many of its decision makers. In addition, HSBC is the single most important stock traded on the HKEx, the main driver of the Hang Seng Index. New York comes last, despite being the largest stock market trading centre of the world (in terms of total trading and the trading of foreign stocks). New York is also the centre of expertise in security analysis, ahead of Hong Kong, and possibly ahead of London as well. Hence, it is not its ability to process publicly available information about HSBC that limits New York's contribution to price discovery. The only explanation is that although HSBC has large operations in North America, New York cannot rival Hong Kong's and particularly London's access to private information with regard to HSBC.

The paper demonstrates that the value of private information in relation to public information on stock markets depends on market conditions. With a bull market still in place in 2006 and early 2007, New York was confident in information it was receiving about $\mathrm{HSBC}$ and its power to interpret this information. It was in late 2007 that the problems building up in the financial sector (in the US first and then spreading internationally) turned public information about banks much less valuable, and eventually (at the peak of the crisis in the months following September 2008) worthless. It was exactly in the period that the advantage of London and Hong Kong over New York increased. Importantly, however, in response to growing uncertainty and pessimism, price discovery did not simply concentrate in London. Rather, the crisis increased the significance of collaboration between London and Hong Kong, searching for the right price. 
The increasing role of Hong Kong during the crisis and in the period of fragile recovery of 2009 seems to reflect the growing emphasis of HSBC on Asian operations as the main driver of the Bank's income and profits. Related to that is an increasing role of Hong Kong as the Bank's decision-making structure. Recall the move of the Chief Executive Officer from London to Hong Kong in 2010, and informal shareholder meetings organized in Hong Kong prior to Annual General Meetings in London. In this context it is interesting to compare my results with those of Agarwal et al. (2007), who showed that in 1996 Hong Kong contributed more to price discovery of HSBC than London. This was 3 years after HSBC moved its headquarters from Hong Kong to London, which suggests that shifts in the locus of price discovery may be slow and subject to considerable inertia. After all crucial private information is located within a social circle of a company's key decision makers and those who interact with them on a regular basis. Michael Geoghegan may move to Hong Kong, but a large part of his social network will remain in London. After 1993, it took several years for HSBC price discovery to move to London. Even if it price discovery moves back to Hong Kong, it is unlikely to happen quickly.

The results have implications for understanding the relationships between financial centres. In his tour-de-force of international financial centres, Youssef Cassis (2005) remarked that herd-behaviour on financial markets is related to the concentration of investors and traders in few financial centres. While I agree with this remark, I would stress that even if there are few dominant sources of information, expertise, and expectations, combining them can still make a big difference. Clark and Wójcik (2001), analyzing the Asian crisis of 1997-8, documented a less pessimistic attitude in New York than in London about the impact of the crisis, which was proved correct by the subsequent performance of the stock markets. They suggested that this advantage of New York was based on more heterogeneous sources of information in New York (coming i.a. from the the high-technology centres of Sillicon Valley and Boston, as well as other large US financial centres like Chicago and Philadelphia). This paper reinforces this point, showing that the role of heterogeneous information is particularly important during market turmoil. Witness the stronger role of the London-Hong Kong duo and trading overlaps between late 2007 and early 2009.

Interpreting the results, we should not jump to conclusions about the role of the location of stock exchanges themselves. London dominates and New York lags behind in price discovery for HSBC, not because the LSE is closer to HSBC's headquarters but because investors trading on the LSE have better access to private information about HSBC. Those who trade on the HKEx have the second best, and those on the NYSE the worst access. Location of the exchange is still closely related to the location of those using it. Despite the fact that the HKEx is fully open to foreign traders, the latter still represent only $40 \%$ of trading activity. US combined with UK-based investors contribute twice less trading than do Hong Kong-based investors. In other words, this paper is about proximity between investors and issuers. It contributes, however, to the debate on the role of proximity between stock exchanges on the one side and investors, issuers and other intermediaries on the other side in the operation of stock markets (Wójcik 2007). 


\section{Acknowledgements}

I am grateful for comments from Gordon L Clark and Najat El Mekkaoui de Freitas. I would also like to acknowledge the financial support of he British Academy (SG54019).

\section{References}

Agarwal, S., Liu, C., Rhee, S.G. (2007) Where does price discovery occur for stocks traded in multiple markets? Evidence from Hong Kong and London, Journal of International Money and Finance, 26, 46-63.

Anand, A., Subrahmanyam, A. (2008) Information and the intermediary: Are market intermediaries informed traders in electronic markets? Journal of Financial and Quantitative Analysis, 43 (1), 1-28.

Anand, A., Gatchev, V.A., Madureira, L., Pirinsky, C. A., and Underwood, S. (2008) Geographic Proximity and Price Discovery: Evidence from Nasdaq. Available at SSRN: http://ssrn.com/abstract=1032633

Barber, B.M., and Odean, T. (2008) All that glitters: The effect of attention and news on the buying behavior of individual and institutional investors. Review of Financial Studies, 21, 785-815.

Barclay, M.J., Warner, J.B. (1993) Stealth trading and volatility. Which trades moves prices? Journal of Financial Economics, 34, 281-305.

Chan, K., Menkveld, A.J., Yang, Z. (2007) The informativeness of domestic and foreign investors' trades: Evidence from the perfectly segmented Chinese market. Journal of Financial Markets, 10, 391-415.

Clark, G.L., Thrift, N. (2005) The return of bureaucracy: Managing dispersed knowledge in global finance. In K. Knorr Cetina and A. Preda, The Sociology of Financial Markets. Oxford: Oxford University Press, 229-249.

Clark, G.L., Wójcik, D., Bauer, R. (2006) Geographically dispersed ownership and inter-market stock price arbitrage - Ahold's crisis of corporate governance and its implications for global standards. Journal of Economic Geography, 6, 303-322.

Clark, G.L., Wójcik, D. (2001) The City of London in the Asian crisis. Journal of Economic Geography, 1, 107-130.

Halling, M., Pagano, M., Randl, O., Zechner, J. (2008) Where is the market? Evidence from cross-listings in the United States. Review of Financial Studies, 21, 725-761.

Harris, L. (2003) Trading and Exchanges. Market Microstructure for Practitioners. Oxford: Oxford University Press.

Hupperets, E.C.J., Menkveld, A.J. (2002) Intraday analysis of market integration: Dutch blue chips traded in Amsterdam and New York. Journal of Financial Markets, 5, 57-82. 
Karolyi, G.A. (2006) The world of cross-listings and cross-listings of the world: Challenging conventional wisdom. Review of Finance, 10, 99-152.

Karolyi, G.A. (2003) DaimlerChrysler AG, the first truly global share. Journal of Corporate Finance, 9, 409-30.

Markwat, T., Kole, E., van Dijk, D. (2009) Contagion as a domino effect in global stock markets. Journal of Banking and Finance 33, 1996-2012.

Menkveld, A.J., Koopman, S.J., Lucas, A. (2007) Modeling around the clock price discovery for cross-listed stocks using state space methods. Journal of Business \& Economic Statistics, 25, 213-225.

Pascual, R., Pascual-Fuster, B., Climent, F. (2006) Cross-listing, price discovery and the informativeness of the trading process. Journal of Financial Markets, 9, 144-161.

Sonney, F. (2009) Financial analysts' performance: Sector versus country specialization. Review of Financial Studies, 22 (5), 2087-2131.

Wang, J., Gulser, M., Liu, Z., Meric, I. (2009) Stock market crashes, firm characteristics, and stock returns. Journal of Banking and Finance, 33, 15631574.

Werner, I.M., Kleidon, A.W. (1996) U.K. and U.S. trading of British cross-listed stocks: An intraday analysis of market integration. Review of Financial Studies, 9, 619-664.

Wójcik, D. (2010) Listing BRICs: Stock issuers from Brazil, Russia, India and China in New York, London and Luxembourg. Economic Geography (forthcoming). http://papers.ssrn.com/sol3/papers.cfm?abstract_id=1431511 (working paper)

Wójcik, D. (2009a) Proximity in secondary equity markets, In Clark, G.L., Dixon, A. and Monk, A. (eds) Managing Financial Risks: From Global to Local, Oxford University Press, 140-62.

Wójcik, D. (2009b) Financial centre bias in primary equity markets, Cambridge Journal of Regions, Economy and Society 2(2), pp. 193-210.

Wójcik, D. (2007) Geography and the future of stock exchanges: between real and virtual space. Growth and Change, 38 (2), 200-223. 
Table 1. HSBC's total operating income by region

\begin{tabular}{lrrrr}
\hline & 2009 & 2008 & 2007 & 2006 \\
\hline Europe & 35 & 37 & 34 & 33 \\
Hong Kong & 17 & 13 & 17 & 15 \\
Rest of Asia (inc. & & & & \\
Middle East) & 13 & 13 & 11 & 10 \\
North America & 21 & 23 & 26 & 31 \\
Latin America & 13 & 13 & 12 & 11 \\
Total & 100 & 100 & 100 & 100 \\
\hline
\end{tabular}

Source: Author's calculations based on data from HSBC Annual Reports

Figure 1. Stock market performance 2006-9

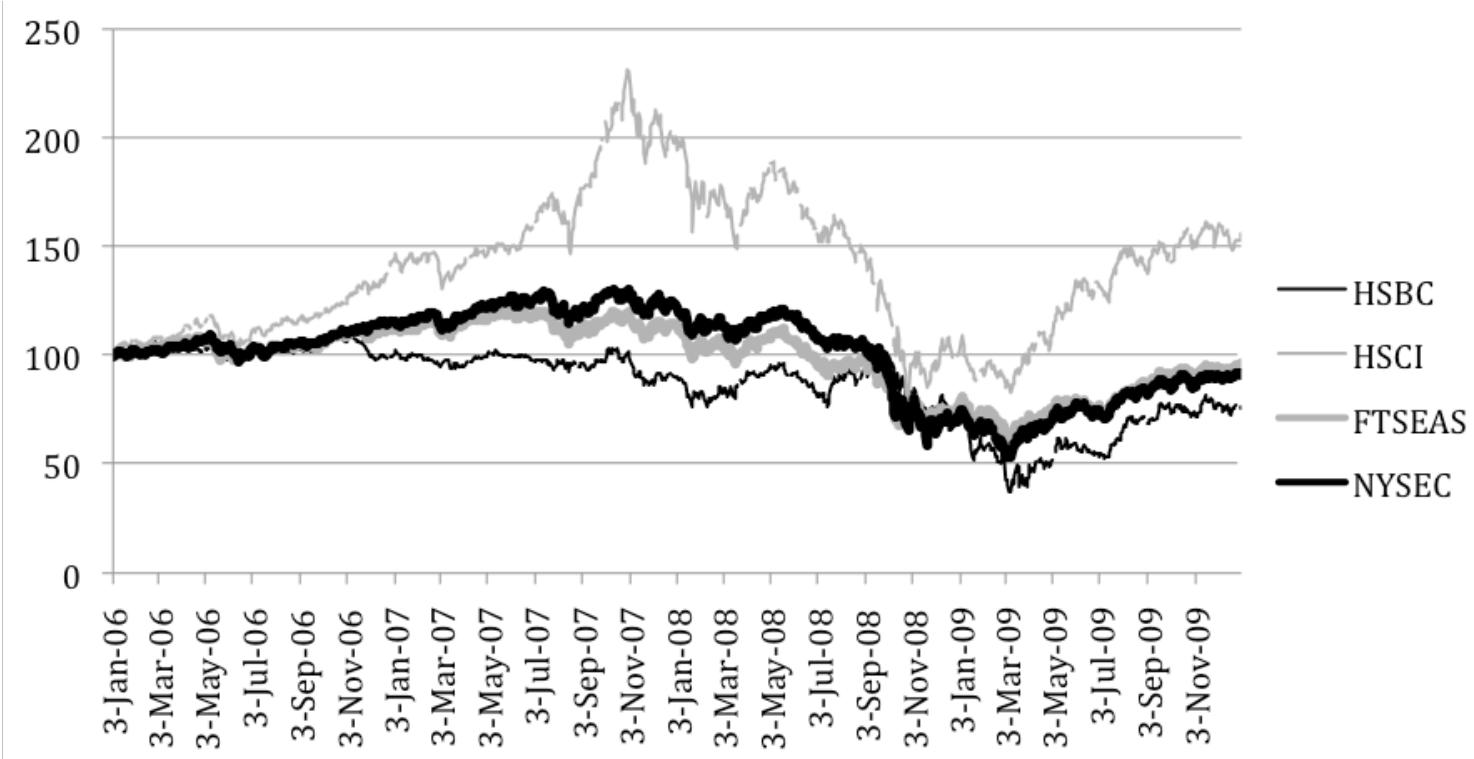

Note: Hang Seng Composite Index (HSCI), FTSE All Share (FTSEAS), NYSE Composite (NYSEC) Source: Author's calculations based on data from Factiva (also for table 2, figure 3, figure 4, table 3, and appendix 1)

Table 2. Standard deviation of daily returns

\begin{tabular}{lrrrrrr}
\hline \multicolumn{1}{c}{ Period } & HSCI & FTSEAS & NYSECI & $\begin{array}{c}\text { HSBC- } \\
\text { HK }\end{array}$ & $\begin{array}{c}\text { HSBC- } \\
\text { LO }\end{array}$ & $\begin{array}{c}\text { HSBC- } \\
\text { NY }\end{array}$ \\
\hline 1 (Jan06-Oct07) & 1.21 & 0.90 & 0.83 & 0.79 & 0.90 & 0.92 \\
2 (Nov07-Aug08) & 2.24 & 1.43 & 1.33 & 1.85 & 1.86 & 1.70 \\
3 (Aug08-Feb09) & 3.76 & 2.90 & 3.77 & 4.04 & 3.99 & 4.17 \\
4 (Mar09-Dec09) & 1.83 & 1.37 & 1.74 & 3.32 & 3.50 & 3.38 \\
\hline
\end{tabular}

Note: Standard deviation for HSBC price in Hong Kong (HK), London (LO) and New York (NY) is calculated for prices in HKD, GBP and USD respectively. 
Figure 2. The 24-hour clock of trading HSBC shares

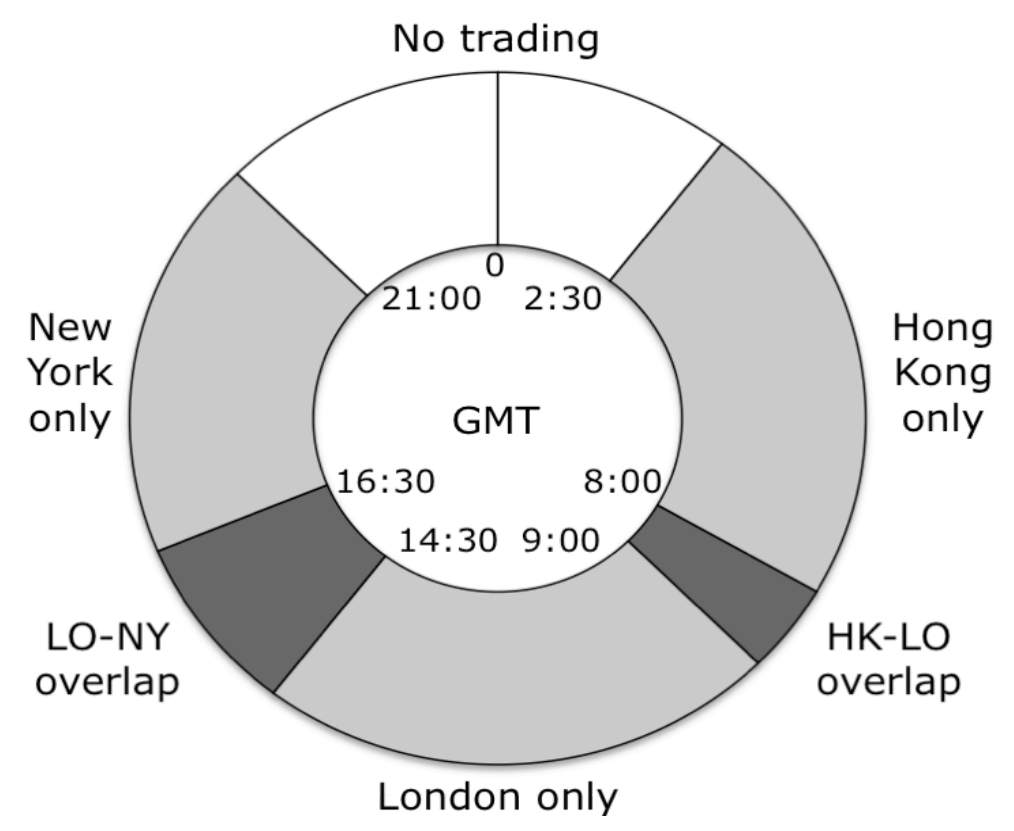

Figure 3. The share of trading phases in absolute price changes

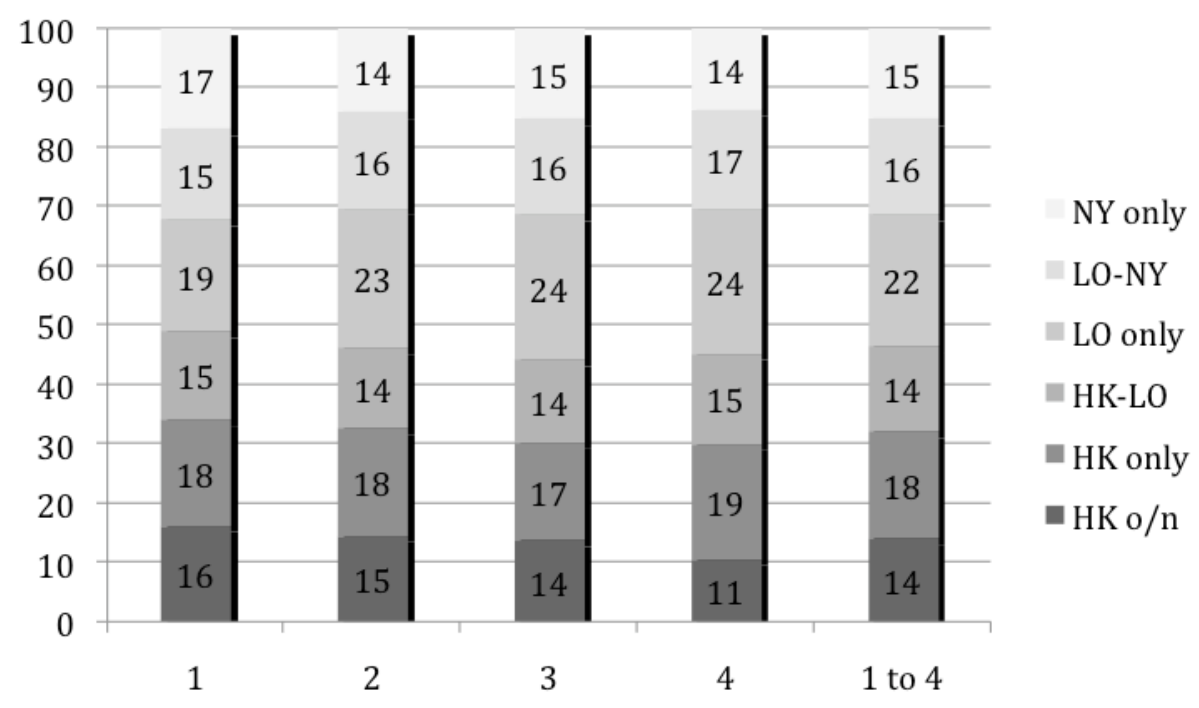


Figure 4. Price impact on the next market

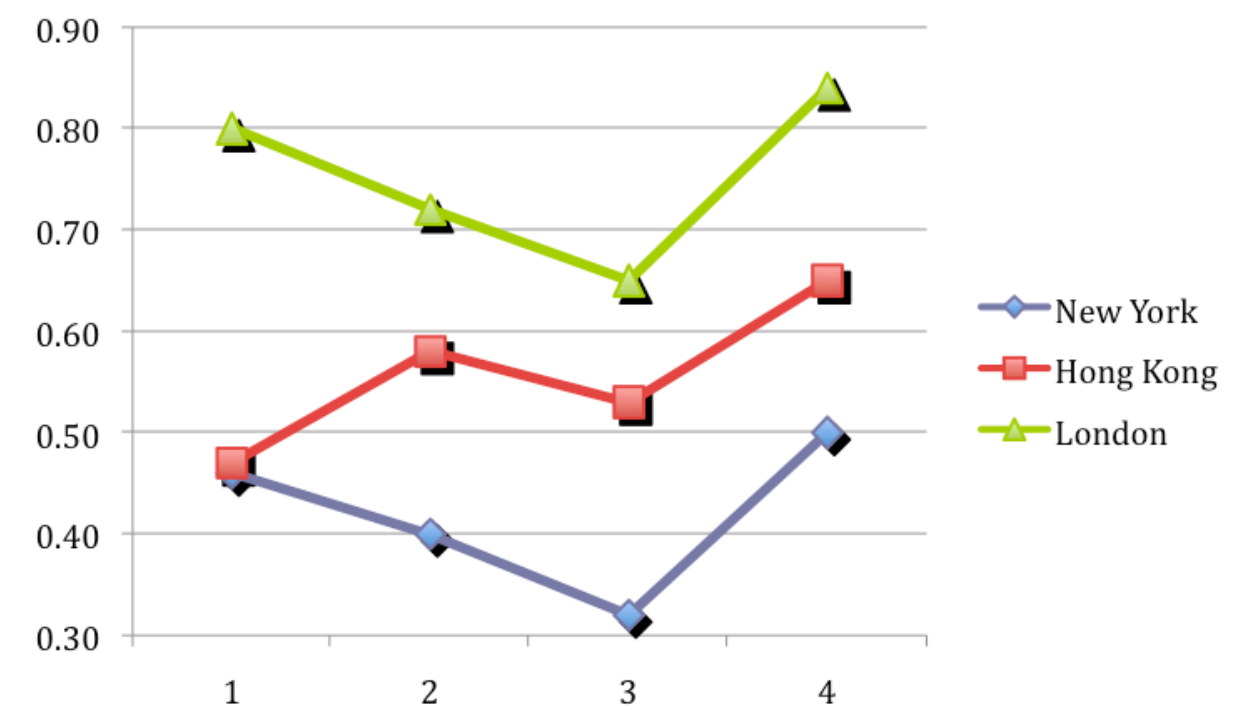

Table 3. Average trading volume (in millions of shares)

\begin{tabular}{crrr}
\hline Period & $\begin{array}{l}\text { Hong } \\
\text { Kong } \\
\text { (HKEx) }\end{array}$ & \multicolumn{1}{c}{$\begin{array}{c}\text { London } \\
\text { (LSE) }\end{array}$} & \multicolumn{1}{c}{$\begin{array}{c}\text { New York } \\
\text { (NYSE) }\end{array}$} \\
\hline 1 (Jan06-Oct07) & 22.1 & 56.8 & 3.3 \\
2 (Nov07-Aug08) & 28.6 & 56.4 & 9.9 \\
3 (Aug08-Feb09) & 33.3 & 57.3 & 14.6 \\
4 (Mar09-Dec09) & 35.3 & 52.7 & 14.4 \\
1-4 (Jan06-Dec09) & 27.6 & 55.9 & 8.4 \\
\hline
\end{tabular}


Appendix 1. Mean absolute price changes per trading phase and period

\begin{tabular}{|c|c|c|c|c|}
\hline Period & Trading phase & $\begin{array}{l}\text { Mean absolute } \\
\text { price change }\end{array}$ & $\begin{array}{c}\text { Average } \\
\text { duration } \\
\text { (hrs) }\end{array}$ & $\begin{array}{c}\text { Mean } \\
\text { absolute } \\
\text { price } \\
\text { change } \\
\text { per hr }\end{array}$ \\
\hline \multirow{7}{*}{1 (Jan06-Oct07) } & HK overnight & 0.082 & 5 & 0.016 \\
\hline & HK only & 0.090 & 6 & 0.015 \\
\hline & HK-LO overlap & 0.074 & 0.5 & 0.149 \\
\hline & LO only & 0.095 & 6 & 0.016 \\
\hline & LO_NY overlap & 0.077 & 2 & 0.038 \\
\hline & NY only & 0.085 & 4.5 & 0.019 \\
\hline & Total & 0.503 & 24 & 0.253 \\
\hline \multirow{7}{*}{2 (Nov07-Aug08) } & $\mathrm{HK}$ o/n & 0.101 & 5 & 0.020 \\
\hline & HK only & 0.126 & 6 & 0.021 \\
\hline & HK-LO & 0.094 & 0.5 & 0.187 \\
\hline & LO only & 0.162 & 6 & 0.027 \\
\hline & LO-NY & 0.112 & 2 & 0.056 \\
\hline & NY only & 0.097 & 4.5 & 0.022 \\
\hline & Total & 0.692 & 24 & 0.333 \\
\hline \multirow{7}{*}{3 (Aug08-Feb09) } & $\mathrm{HK}$ o/n & 0.149 & 5 & 0.030 \\
\hline & HK only & 0.178 & 6 & 0.030 \\
\hline & HK-LO & 0.150 & 0.5 & 0.301 \\
\hline & LO only & 0.264 & 6 & 0.044 \\
\hline & LO-NY' & 0.174 & 2 & 0.087 \\
\hline & NY only & 0.164 & 4.5 & 0.037 \\
\hline & Total & 1.080 & 24 & 0.528 \\
\hline \multirow{7}{*}{4 (Mar09-Dec09) } & $\mathrm{HK}$ o/n & 0.068 & 5 & 0.014 \\
\hline & HK only & 0.124 & 6 & 0.021 \\
\hline & HK-LO & 0.098 & 0.5 & 0.196 \\
\hline & LO only & 0.156 & 6 & 0.026 \\
\hline & LO-NY & 0.107 & 2 & 0.053 \\
\hline & NY only & 0.088 & 4.5 & 0.019 \\
\hline & Total & 0.641 & 24 & 0.329 \\
\hline \multirow{7}{*}{$\begin{array}{l}\text { The whole period } \\
\text { (Jan06-Dec09) }\end{array}$} & $\mathrm{HK}$ o/n & 0.091 & 5 & 0.018 \\
\hline & HK only & 0.115 & 6 & 0.019 \\
\hline & HK-LO & 0.093 & 0.5 & 0.185 \\
\hline & LO only & 0.142 & 6 & 0.024 \\
\hline & LO-NY & 0.103 & 2 & 0.051 \\
\hline & NY only & 0.098 & 4.5 & 0.022 \\
\hline & Total & 0.642 & 24 & 0.319 \\
\hline
\end{tabular}

